\title{
The Value Relevance of Earnings and Book Value: The Importance of Ownership Concentration and Firm Size
}

\author{
Pathirawasam Chandrapala
}

\begin{abstract}
The purpose of this paper is to investigate the impact of ownership concentration and firm size on value relevance of two accounting variables, earnings and book value, given by firms listed in Colombo Stock Exchange (CSE) in Sri Lanka from 2005 to 2009. Using pooled cross-sectional data regressions, the study finds that the value relevance of earnings and book value is below average. The value relevance of ownership concentrated firms is higher than that of ownership non-concentrated firms. Further, the two variables show higher value relevance for larger firms than for smaller firms. Contrary to the previous findings of the author, the study finds that book value is more value relevant than the earnings in Sri Lanka.
\end{abstract}

Key words: Accounting information, book value, earnings, ownership concentration, firm size.

\section{INTRODUCTION}

The information content of accounting numbers in ascertaining security prices/returns is one of the most fundamental issues in finance and accounting. Ball and Brown (1968) report the first literature in this regards. They find that unexpected earnings are significantly related to abnormal stock returns. Since, then many researchers have examined the information content of accounting numbers in various markets. (e.g., Collings, Magdew and Weiss, 1997; Frankel and Lee,1998; Brimble and Hodgson ,2007; Pathirawasam, 2010).

The main purpose of financial statements is to give a true and fair view of the company's operations and financial position. If there is no relationship between firm value and numbers in the financial statements, such statements have no value relevance. If the financial statements lose the value relevance, no body will have an interest on them. Therefore, the empirical investigation of value relevance of accounting information is a direct check of the validity and reliability of financial statements published by companies. Further, according to agency theory, managers don't all the time take decisions to maximize shareholders' value (Thomsen and Pedersen, 2000). Therefore, the relationship between ownership concentration as a mechanism to influence managers, and value relevance of accounting information is worth to examine. In the same way, researchers argue that financial statements of large firms are in higher quality than that of small firms. Hence, the value relevance of financial information of large firms may higher than that of small firms. However, empirical findings on this issue give mixed results (e.g., Bae and Jeong, 2007; Brimble and Hodgson, 2007).

The author's previous study examines the value relevance of earnings and book value in the CSE from 2006-2009. The author finds that earnings and book value have value relevance using stock price as dependent variable. However, the author has not examined how the value relevance of accounting information relates with ownership concentration and firm size. 
Therefore, the purpose of this study is to re-examine the value relevance of accounting information in Sri Lankan context by improving some innovations to the value relevance model used in Pathirawasam (2010). This study varies from the previous study of the author in three aspects. (i) The previous paper was based on the sample of 129 companies consisting largest 6 sectors in the CSE. However, this study considers all the listed securities since 2005 to 2009 for the analysis.

(ii) Explanatory power of the accounting variables is examined for both large stocks as well as small stocks. (iii) Impact of ownership concentration is examined on the value relevance of earnings and book value model. The pooled data analysis regression is used to analyze the data.

The remaining of the paper is organized as follows. The section 2 presents the review of literature. Section 3 explains sample and methodology and section 4 contains results of the analysis. The last section is the conclusion of the study.

\section{REVIEW OF LITERATURE}

Most of the early empirical evidence on value relevance of accounting information comes from United States (U.S) market. Hayn (1995) examines the value relevance of earnings on stock returns over the period from 1962 to 1990 . The author finds that earnings are positively associated with stock returns. However, when pooled data of only profitable firms are considered, stock price movements are much more strongly link to returns. Collings, Magdew and Weiss (1997) find that both earnings and book value significantly relate with market value over forty years from 1953-1993. Barth, Beaver and Landsman (1998) find that the explanatory power of earnings and book value variables systematically varies across industries.

Frankel and Lee (1998) explore relationships between share prices and accounting variables using data from 20 countries. They find that current earnings, current book value and earnings forecasts jointly explain the variability of share prices of 72 percent on average. King and Langli (1998) find that both book value and earnings are significantly related to share prices in Germany, Norway and the United Kingdom. However, the combined explanatory power of three variables is about $70 \%$ in the United Kingdom, 60\% in Norway and 40\% in Germany. They further find that explanatory power of the variables are differs in the accounting systems of the three countries. Book value explains more than earnings in Germany and Norway but less than earnings in United Kingdom. In another study of international accounting differences, Graham (2000) examines value relevance of book value per share and current residual income in Indonesia, Malaysia, Phillippine, South Korea, Thaiwan and Thailand. They find that coefficients of these variables are statistically significant for all the countries. The explanatory power of the model ranges from $24 \%$ in Thailand to $90 \%$ in Philippines.

Pathirawasm (2010) investigates the value relevance of earnings, book value and return on equity on share price in CSE. Sample of the study includes 129 companies selected from 6 major sectors in the CSE. Cross sectional and time series cross-sectional regressions are used for the data analysis. Study finds that earnings, book value and return on equity have positive value relevance on market value of securities. The most valve relevant variable is the earnings while the least value relevanct variable is the return on equity in Sri Lanka. The explanatry power of the model has increased over the sampla time. New technology adoption at the CSE in 2007 has considerably increased the value relevance of accounting based earning information (EPS and ROE) in 
Sri Lanka. However, the incremental value relevance of the BVPS is negative during the period considered for the study.

\subsection{Ownership concentration}

Agency theory explains the relationship between owners and managers. Generally accepted assumption is that owners desire to maximize profits or wealth at the same time managers may have other interests such as high compensation, low effort levels, expense preference, empire buildings etc. Thomsen and Pedersen (2000) report that:

In studies of diversification strategy, top managers are assumed to have a personal interest in (product or geographical) diversification at the corporate level because of (employment) risk aversion, expense preference, and empire building. However concentrated ownership might counteract corporate diversification and increase shareholder value.

Therefore, ownership concentration is one of the pre-requisites to influence on managers activities. As referred in Thomsen and Pedersen (2000), Zechhouser and Pownd (1990) find that price-to-earnings ratio and ownership concentration has a positive relationship. Further, Thomsen and Pedersen (2000), taking a sample of 435 of largest European companies, find that after controlling for other variables, ownership concentration has a positive relation with market-tobook value of equity as well as return on asset. However, the effect is level off for high ownership shares. Further, they find that ownership identity has important implications for corporate strategy and performance. More recently, Leng (2004) finds that after controlling the effects of other factors, proportion of shares held by institutional investors significantly influenced on return on equity in Malaysian listed companies. Bae and Jeong (2007) examine the quality of earnings and book value provided by firms with ownership is concentrated on the chaebols (Korea Fair Trade Association) and other firms. They find that ownership concentrated firms tend to provide less value-relevant earnings and book value. The value relevance difference between ownership concentrated firms and non-concentrated firms ranging from -6.0 percent to -19.9 percent respectively.

\subsection{Firm Size and value relevance}

Prior studies indicate that the firm size is a key factor which determine the value relevance of accounting information (e.g. Bae and Jeong, 2007; Brimble and Hodgson, 2007). Brimble and Hodgson (2007) point out that the value relevance of large firms is higher than that of small firms due to some reasons as follows:

... this is related to the relative information environment, such a lower level of analyst following for small firms compared to large firms, bigher levels of information disclosure by larger firms, greater number of start-up firms in the small firm category, and the greater propensity of small firms to report losses.

Brimble and Hodgson (2007) examine the value relevance of earnings and book value information in Australian Stock Exchange from 1974 to 2001. They find low value relevance of earnings, book value and combine variables as $0.10,0.09$ and 0.16 percent respectively. Further, they report that explanatory power for small firms is much higher when compared to large firms.

Hodgson and Clarke (2000) examine the value relevance of earnings and cash flows for 121 companies listed in Australian Stock Exchange from 1989-1996. Using annual stock returns as the dependent variable, they find that explanatory power and earnings response coefficients are 
more pronounce for large firms than small firms. Further, Bae and Jeong (2007) find that value relevance of accounting information to stock price is significantly smaller for chaebol-affiliated firms $\left(\mathrm{R}^{2}=25 \%\right)$ and below average for whole sample $\left(\mathrm{R}^{2}=34.5 \%\right)$. They also find that larger firms have higher explanatory power. For the group of larger firms, the chaebol and non- chaebol firms have adjusted $\mathrm{R}^{2} \mathrm{~s}$ of 27.3 and 44.5 percent, respectively. For the group of small firms, they have adjusted $\mathrm{R}^{2} \mathrm{~S}$ of 2.9 and 25.6 percent for the chaebol and non- chaebol firms respectively. Chan and Zhang (2007) examine the cross-sectional relationship between firm accounting variables (earnings yield, capital investment, and change in profitability, growth opportunities and discount rate) and stock returns from 1983-2001 using data from CRSP data file. They find that all identified factors are highly significant $\left(\mathrm{R}^{2}=16 \%\right)$. Further, they report that there is no obvious indication of an increasing or decreasing trend for the adjusted $\mathrm{R}^{2}$ as size increase.

\section{SAMPLE AND METHODOLOGY}

\subsection{Sample}

The sample consists of 924 firm/year observations of companies that are listed in the CSE during the period 2005-2009. The earnings, book value and ownership data were obtained from CSE website (www.cse.lk), which provides financial statements for all the listed firms in the CSE. The price data and market capitalization data were obtained from the CSE data library 2010. The observations with incomplete data records were deleted from the sample. Further, in accordance with the Collings, Magdew and Weiss (1997), observations having standard residuals greater than 4 were excluded from the sample. Therefore, the final sample includes $882 \mathrm{firm} / \mathrm{year}$ observations.

\subsection{Methodology}

The idea of value relevance research is to establish a relationship between market values of equity and accounting variables. This can formally expressed as follows.

$M V E=f(A I)$

Where

MVE = market value of equity

$\mathrm{AI}=$ accounting information

This study adopts the Ohlson (1995) model framework that it provides a link between share price and two accounting variables. The following valuation model is consisting of the earnings and book value. Therefore, the value relevance of accounting information model used in this study is similar to the models used by Francis and Schipper (1999), Collings, Magdew and Weiss (1997), King and Langli (1998), Bao and Chow (1999) and Pathirawasam (2010) ${ }^{1}$.

$P_{i t}=\beta_{0}+\beta_{1} B V_{i t}+\beta_{2} E_{i t}+\varepsilon_{i t}$

Where,

$\mathrm{BV}=$ book value per share

1 The author used Return on Equity (ROE) in addition to earnings and book value. However, the explanatory power of ROE was very small comparing to the other two variables. Therefore, ROE has not been included in the value relevance of accounting information model of this study. 
$\mathrm{E}=$ earnings per share

$i=$ company

$t=$ time (year)

In order to avoid look-ahead bias problem recognized by Banz and Breen (1986) the dependent variable is taken as price of shares 3 months after the end of financial year. Look-ahead is a bias caused by using data which are not yet available but assumes to be available.

Actually, accounting information will come to investors' hand when they receive the annual report of the company and not at the last date of financial year.

This study uses the adjusted coefficient of determination (adj. R2) as the unit to measure the value relevance of earnings and book value. The following equations are estimated to separately analyze the explanatory power that earnings and book value have for price.

$P_{i t}=\beta_{0}+\beta_{1} B V_{i t}+\varepsilon_{i t}$

The equation 3 examines the relationship between price of share and book value.

$P_{i t}=\beta_{0}+\beta_{1} E_{i t}+\varepsilon_{i t}$

The equation 4 examines the relationship between price of share and earnings.

The above regression models are estimated for the total sample and sub samples of ownership structures and firm size.

According to ownership structure, firms are divided into two groups.

1. Ownership concentrated firms

2. Ownership non-concentrated firms

According to Thomsen and Pedersen (2000) Ownership share (votes) of the largest owner is used as the criterion to distinguish ownership concentrated firms from the ownership non-concentrated firms. If the major shareholder's ownership stake is more than 50 percent it is considered as an ownership concentrated firm and vise versa. 440 of the firm/year observations are identified under ownership concentrated group and 442 firm/year observations are identified under ownership non-concentrated group.

In accordance with Hodgson and Clarke (2000) market capitalization is used as the criterion for classifying the sample into two size based sub samples. Firms with a market capitalization less than median market capitalization of all the listed firms are designated as small firms and those with a market capitalization greater than the median are designated as large firms. The large size sub sample has 468 firm/year observations and the small size sub sample has 414 firm year observations.

\section{FINDINGS}

\subsection{Value relevance of earnings and book value: All firms}

Table 1 presents the estimation results of pooled cross-sectional regression of price on earnings and book value. The sample consists of 882 firm/year observations for all the companies listed in the CSE. 
Tab. 1 - Value relevance of earnings and book value for all firms. Source: Own

\begin{tabular}{|c|c|c|c|c|}
\hline \multirow{2}{*}{ Model } & \multicolumn{2}{|c|}{ Regression coefficients } & \multirow{2}{*}{ Adj. $\mathrm{R}^{2}$} & \multirow{2}{*}{ F-value } \\
\cline { 2 - 3 } & $\mathrm{E}$ & $\mathrm{BV}$ & & \\
\hline 2 & $0.916(6.64)$ & $0.552(19.55)$ & 45.46 & 368.24 \\
\hline 3 & - & $0.645(25.69)$ & 42.79 & 660.03 \\
\hline 4 & $2.255(13.71)$ & - & 21.82 & 246.94 \\
\hline
\end{tabular}

Notes:

$\mathrm{t}$-values are reported in parenthesis

Regression models are based on the following equations

Model 2. $P_{i t}=\beta_{0}+\beta_{1} B V_{i t}+\beta_{2} E_{i t}+\varepsilon_{i t}$

Model 3. $P_{i t}=\beta_{0}+\beta_{1} B V_{i t}+\varepsilon_{i t}$

Model 4. $P_{i t}=\beta_{0}+\beta_{1} E_{i t}+\varepsilon_{i t}$

The adj. $\mathrm{R}^{2}$ for the pooled cross-sectional time-series regression indicates that earnings and book value jointly explain about 45 percent $(\mathrm{F}=368.24$ at $\mathrm{P}<0.01)$ of the cross-sectional variation in stock prices of the whole sample. Both of the regressors are significantly related to stock prices. This result is similar to Bae and Jeong (2007) and Pathirawasam (2010). However, the explanatory power of earnings and book value of Sri Lankan firms are significantly lower than that of developed countries. For instance, Collings, Magdew and Weiss (1997) report that earnings and book values explain about 75 percent of U.S. firms' stock prices. The model 3 and 4 examine the univariate regression results for the two accounting variables separately. The both models reveal that book value and earnings significantly relate with the share prices. However, the adj. $\mathrm{R}^{2} \mathrm{~s}$ for the book value is 42.79 percent while the corresponding figure is 21.82 percent for the earnings. Therefore, the explanatory power of book value is 20.97 percent higher than that of the earnings. However, Pathirawasam (2010) found opposite patterns of expanatory powers but, this finding is similar to the Bae and Jeong (2007) and King and Langi (1998) for their Norway and German sample.

\subsection{Value relevance of accounting information and ownership structure}

The table 2 presents the estimated regression results of pooled cross-sectional regression of price on earnings and book value. The regression coefficients are estimated on two groups. Out of 882 observations 440 observations are classified as concentrated ownership while 442 observations are classified as non-concentrated firms.

Ownership concentrated firms have better corporate governance practices. As a result, ownership concentrated firms may reflect more value relevance of accounting information than ownership non-concentrated firms. Therefore, in this sub-section, adj. $\mathrm{R}^{2} \mathrm{~s}$ of model (2) to (4) are examined for ownership concentrated firms as well as for ownership non-concentrated firms.

Table 2 presents number of interesting findings. First, consistent with the agency theory, ownership concentrated firms provide more value relevant information. The adj. $\mathrm{R}^{2}$ for the ownership concentrated firms on model (2) is 56.42 percent $(\mathrm{F}=285.22$ at $\mathrm{P}<0.01)$, while the corresponding number for the ownership non-concentrated group is only 40.63 percent $(F=152.27$ at $\mathrm{P}<0.01)$. The difference between the ownership concentrated and non- concentrated firms is 15.79 percent. This finding is quite different from Bae and Jeong (2007). Second, the value relevance of earnings as well as book value is higher for ownership concentrated firms. The adj. $\mathrm{R}^{2}$ of model (3) for ownership concentrated firms is 52.87 percent $(\mathrm{F}=493.58$ at $\mathrm{P}<0.01)$ while 
the corresponding figure for ownership non-concentrated firms is 37.89 percent $(\mathrm{F}=270.72$ at $\mathrm{P}<0.01)$. The difference of adj. $\mathrm{R}^{2}$ between the ownership concentrated and non-concentrated firms ranging from 14.98 percent. The similar pattern is true for model (4) also. Where, adjusted for ownership concentrated firm is 24.37 percent $(\mathrm{F}=142.48$ at $\mathrm{P}<0.01)$ while the corresponding figure for ownership non-concentrated firms is 21.38 ( $\mathrm{F}=121.24$ at $\mathrm{P}<0.01)$. The difference between adj. $\mathrm{R}^{2} \mathrm{~S}$ of ownership concentrated and non-concentrated firms is 2.99 . This finding gives strong evidence that information quality of the earnings and book value is poor for ownership non-concentrated firms. To the extent that corporate governance structure of ownership non-concentrated firms poor than the ownership concentrated firms, the above result indicates that poorly governance firms resulting in low value relevance of accounting information. Finally, even after controlling the impact of ownership structure on value relevance, the table 2 reveals that book value information is more value relevant than that of the earnings.

Tab. 2 - Value relevance of earnings and book value with ownership concentration. Source: Own

\begin{tabular}{|c|c|c|c|c|c|c|c|c|}
\hline \multirow{2}{*}{ Model } & \multicolumn{4}{|c|}{ Concentrated ownership } & \multicolumn{4}{c|}{ Non concentrated ownership } \\
\cline { 2 - 9 } & E & BV & Adj.R 2 & F-value & E & BV & Adj. R & F-value \\
\hline 2 & $\begin{array}{c}1.252 \\
(6.05)\end{array}$ & $\begin{array}{c}0.732 \\
(17.97)\end{array}$ & 56.42 & 285.22 & $\begin{array}{c}0.830 \\
(4.61)\end{array}$ & $\begin{array}{c}0.451 \\
(11.99)\end{array}$ & 40.63 & 152.27 \\
\hline 3 & - & $\begin{array}{c}0.842 \\
(22.21)\end{array}$ & 52.87 & 493.58 & - & $\begin{array}{c}0.541 \\
(16.45)\end{array}$ & 37.89 & 270.72 \\
\hline 4 & $\begin{array}{c}2.912 \\
(11.93)\end{array}$ & - & 24.37 & 142.48 & $\begin{array}{c}1.948 \\
(11.01)\end{array}$ & - & 21.38 & 121.24 \\
\hline
\end{tabular}

Notes:

$\mathrm{t}$-values are reported in parenthesis

Regression models are based on the following equations

Model 2. $P_{i t}=\beta_{0}+\beta_{1} B V_{i t}+\beta_{2} E_{i t}+\varepsilon_{i t}$

Model 3. $P_{i t}=\beta_{0}+\beta_{1} B V_{i t}+\varepsilon_{i t}$

Model 4. $P_{i t}=\beta_{0}+\beta_{1} E_{i t}+\varepsilon_{i t}$

\subsection{Value relevance of accounting information and firm size}

The table 3 presents the results for value relevance of earnings and book value by estimating equations (2)-(4) for large and small firms. Out of the 882 firm/year observations, 468 are affiliated with large firms while 414 are classified under small firms. Therefore, there is no larger difference of number of observations between two size groups.

Prior studies give mixed results of the value relevance of earning and book value information on size of the firm (Hodgson and Clarke, 2000; Chan and Zhang, 2007; Bae and Jeong, 2007). The results reported in table 3 show that larger firms have higher adj. $\mathrm{R}^{2}$ for the all firms (model 2). Larger firms show an adj. $\mathrm{R}^{2}$ of 53.09 percent $(\mathrm{F}=265.27$ at $\mathrm{P}<0.01)$, while corresponding figure for small firms is 38.02 percent $(\mathrm{F}=129.70$ at $\mathrm{P}<0.01)$. The difference between the adj. R2 is 15.07 percent. This is similar to Hodgson and Clarke, 2000; Bae and Jeong (2007) but contradictory with Brimble and Hodgson (2007). Model 3 and 4 further to confirm that value relevance of large firms is greater than that of small firms. 
Tab. 3 - Value relevance of earnings and book value with firm size. Source: Own

\begin{tabular}{|c|c|c|c|c|c|c|c|c|}
\hline \multirow{2}{*}{ Model } & \multicolumn{4}{|c|}{ Small firms } & \multicolumn{5}{c|}{ Large firms } \\
\cline { 2 - 9 } & E & BV & Adj.R2 & F-value & E & BV & Adj.R2 & F-value \\
\hline 2 & $\begin{array}{c}1.624 \\
(6.11)\end{array}$ & $\begin{array}{c}0.598 \\
(14.98)\end{array}$ & 53.09 & 265.27 & $\begin{array}{c}0.763 \\
(5.15)\end{array}$ & $\begin{array}{c}0.409 \\
(10.84)\end{array}$ & 38.02 & 129.70 \\
\hline 3 & - & $\begin{array}{c}0.735 \\
(21.38)\end{array}$ & 49.42 & 457.34 & - & $\begin{array}{c}0.502 \\
(14.67)\end{array}$ & 34.18 & 215.47 \\
\hline 4 & $\begin{array}{c}3.85 \\
(14.38)\end{array}$ & - & 30.58 & 206.80 & $\begin{array}{c}1.529 \\
(10.36)\end{array}$ & - & 20.48 & 107.38 \\
\hline
\end{tabular}

Notes:

$\mathrm{t}$-values are reported in parenthesis

Regression models are based on the following equations

Model 2. $P_{\mathrm{itt}}=\beta_{0}+\beta_{1} B V_{\mathrm{it}}+\beta_{2} \mathrm{E}_{\mathrm{it}}+\varepsilon_{\mathrm{it}}$

Model 3. $P_{\text {it }}=\beta_{0}+\beta_{1} B V_{\text {it }}+\varepsilon_{\text {it }}$

Model 4. $P_{i t}=\beta_{0}+\beta_{1} E_{i t}+\varepsilon_{\text {it }}$

The higher value relevance of book value and earnings of large firms over the small firms may be due to the relative information coverage by analysts. As suggested by Hodgson and Clarke (2000) this may be due to the lower level of analysts following for small firms comparing to large firms. Further, large firms may disclose high level of information than small firms.

\section{CONCLUSIONS}

Recent research on value relevance of accounting information has investigated the effect of corporate governance mechanisms and firm size on quality of accounting information. The general norm is that effective corporate governance practices are associated with better quality accounting information. Further, size of the firm also positively relate with quality of accounting information. This study extends the previous study of the author (Pathirawasam, 2010) by examining the effect of governance mechanism and firm size on value relevance of accounting information for all the listed companies in Sri Lanka. Using the cross-sectional pooled regression technique, this study uncovered several interesting results.

First, study finds that value relevance of earnings and book value is below average and this is similar to the previous finding of the author. Second, ownership concentrated firms provide more value relevant information than ownership non-concentrated firms. Third, large firms have higher level of earnings and book value information than small firms. Fourth, after controlling the effects of ownership structure and firm size, value relevance of book value information is greater than earnings information and it is contrary to the previous finding.

This study attempted to measure the value relevance of earnings and book value. The joint explanatory power of the two variables is below average. This implies that there may be some omitted variables that would have increased the explanatory power if they were added to the model (2). In addition to earnings and book value, cash flow, research and development, dividends and ownership identity are shown to be variables in empirical valuation models (e.g., Dechow, 1994; Callen and Morel, 2005; Ohlson, 1995; Pederson and Thomsen, 2003). Therefore, further extension of the value relevance model is possible by including above factors to the model (2). 


\section{References}

1. Bae, K.H., \& Jeong, S.W. (2007). The value-relevance of earnings and book value, ownership structure, and business group affiliation: Evidence from Korean Business Groups. Journal of Business Finance \& Accounting, 34(5), 740-766. http://dx.doi.org/10.1111/ j.1468-5957.2007.02017.x

2. Ball, R., \& Brown, P. (1968). An empirical evaluation of accounting income numbers. Journal of Accounting Research, 6(2), 159-178. http://dx.doi.org/10.2307/2490232

3. Banz, R., \& Breen, W. (1986). Sample dependent results using accounting and marketing data: Some evidence. Journal of Finance, 41(4), 779-793. http://dx.doi.org/10.1111/j.15406261.1986.tb04548.x

4. Bao, B.H., \& Chow, L. (1999). The usefulness of earnings and book values for equity valuation in emerging capital markets: Evidence from listed companies in the People's Republic of China. Journal of International Financial Management and Accounting, 10(2), 85-104. http://dx.doi.org/10.1111/1467-646X.00045

5. Barth, M.E., Beaver, W.H., \& Landsman, W.R. (1998). Relative valuation roles of equity book values and net income as a fiunction of financial health. Journal of Accounting and Economics, 25(1), 1-34. http://dx.doi.org/10.1016/S0165-4101(98)00017-2

6. Brimble, M., \& Hodgson, A. (2007). On the intertemporal value relevance of conventional financial accounting in Australia. Accounting and Finance, 47(4), 599-622. http://dx.doi. org/10.1111/j.1467-629X.2007.00241.x

7. Callen, J.L., \& Morel, M. (2005). The valuation relevance of R\&D expenditures: time series evidence. International Review of Financial Analysis, 14(3), 304-325. http://dx.doi.org/10.1016/ j.irfa.2004.10.007

8. Chen, P., \& Zhang, G. (2007). How do accounting variables explain stock pricemovements? Theory and evidence. Journal of Accounting and Economics, 43(2-3), 219-244. http://dx.doi. org/10.1016/j.jacceco.2007.01.001

9. Collins, D.W., Maydew, E.L., \& Weiss, L.S. (1997). Changes in the value-relevance of earnings and book values over the past forty years. Journal of Accounting \& Economics, 24(1), 143-181. http://dx.doi.org/10.1016/S0165-4101(97)00015-3

10. Dechow, M.P. (1994). Accounting earnings and cash flows as measures of firm performance: The role of accounting accruals. Journal of Accounting \& Economics, 18(1), 3-42. http://dx.doi.org/10.1016/0165-4101(94)90016-7

11. Francis, J., \& Schipper, K. (1999). Have financial statements lost their relevance? Journal of Accounting Research, 37(2), 319-352. http://dx.doi.org/10.2307/2491412

12. Frankel, R., \& Lee, C. M. C. (1998). Accounting diversity and international valuation. Working paper. University of Michigan and Cornell University.

13. Graham, R., \& King, R. (2000). Accounting practices and the market valuation of accounting numbers: Evidence from Indonesia, Korea, Malaysia, the Philippines, Taiwan, and Thailand. The International Journal of Accounting, 35(4), 445-470.

14. Hayn, C. (1995). The information content of losses. Journal of Accounting \& Economics, 20(2), 125-153. http://dx.doi.org/10.1016/0165-4101(95)00397-2

15. Hodgson, A., \& Clarke, S.P. (2000). Earnings, chasflow and returns: functional relations and the impact of firm size. Accounting and Finance, 40(1), 51-73. http://dx.doi. org/10.1111/1467-629X.00035 
16. King, R.D., \& Langli, J.C. (1998). Accounting diversity and firm valuation. International Journal of Accounting, 33(4), 529-567. http://dx.doi.org/10.1016/S0020-7063(98)90012-7

17. Leng, A.A.C. (2004). The Impact of Corporate Governance Practices on Firms Financial Performance: Evidence from Malaysian Companies. SEAN Economic Bulletin, 21(3), 308-318. http://dx.doi.org/10.1355/AE21-3D

18. Ohlson, A.J. (1995). Earnings, book values and dividends in security valuation. Contemporary Accounting Research, 11(2), 661-687.

19. Pathirawasam, C. (2010). Value relevance of accounting information: evidence from Sri Lanka. International Journal of Research in Commerce \& Management, 8(1), 13-20.

20. Thomsen, S., \& Pedersen, T. (2000). Ownership structure and value of the largest European firms: The importance of owner identity. Strategic Management Journal, 21(6), 689705. http://dx.doi.org/10.1002/(SICI)1097-0266(200006)21:6<689::AID-SMJ115>3.0.CO;2Y

21. Thomsen, S., \& Pedersen, T. (2003). Ownership structure and economic performance in the largest European companies. Journal of Management and Governance, 7(1), 27-55. http:// dx.doi.org/10.1023/A:1022480016567

\section{Contact information}

dr. Pathirawasam Chandrapala

Department of Commerce and Financial Management

Faculty of Commerce and Management studies

University of Kelaniya, Sri lankea

Email:pathi3@yahoo.com

JEL Classification: F65 